\title{
Polarisation and functional characterisation of hepatocytes derived from human embryonic and mesenchymal stem cells
}

\author{
ANWAR AZAD PALAKKAN ${ }^{1,2}$, ROBERT DRUMMOND ${ }^{1}$, RICHARD ALEXANDER ANDERSON $^{3}$, \\ SEBASTIAN GREENHOUGH ${ }^{4}$, KUMARY TV ${ }^{2}$, DAVID COLIN HAY ${ }^{4}$ and JAMES ALEXANDER ROSS ${ }^{1,4}$ \\ ${ }^{1}$ Tissue Injury and Repair Group, MRC Centre for Regenerative Medicine, The Chancellor's Building, \\ University of Edinburgh, Edinburgh EH16 4SB, Scotland, UK; ${ }^{2}$ Tissue Culture Laboratory, Division of Implant Biology, \\ Biomedical Technology Wing, Sree Chitra Tirunal Institute for Medical Sciences and Technology, Trivandrum, \\ Kerala 695012, India; ${ }^{3}$ MRC Centre for Reproductive Health, The Queen's Medical Research Institute, \\ University of Edinburgh, Edinburgh EH16 4TJ; ${ }^{4}$ MRC Centre for Regenerative Medicine, SCRM Building, \\ Edinburgh BioQuarter, University of Edinburgh, Edinburgh EH16 4UU, Scotland, UK
}

Received May 22, 2015; Accepted May 28, 2015

DOI: 10.3892/br.2015.480

\begin{abstract}
Adult hepatocytes are polarised with their apical and basolateral membranes separated from neighbouring cells by tight junction proteins. Although efficient differentiation of pluripotent stem cells to hepatocytes has been achieved, the formation of proper polarisation in these cells has not been thoroughly investigated. In the present study, human embryonic stem cells (hESCs) and human mesenchymal stem cells (hMSCs) were differentiated to hepatocyte-like cells and the derived hepatocytes were characterised for mature hepatocyte markers. The secretion of hepatic proteins, expression of hepatic genes and the functional hepatic polarisation of stem cell-derived hepatocytes, foetal hepatocytes and the HepG2 hepatic cell line were evaluated and the different lines were compared. The results indicate that hESC-derived hepatocytes are phenotypically more robust and functionally more efficient compared with the hMSC-derived hepatocytes, suggesting their suitability for toxicity studies.
\end{abstract}

\section{Introduction}

Currently, there is significant interest in generating mature hepatocytes from stem cells either for disease modelling, predictive drug toxicology studies or, in the longer term, for transplantation. The scarcity of adult human hepatocytes, and their functional deterioration and poor replication in culture are the main motivations behind this research (1).

Correspondence to: Professor James Alexander Ross, Tissue Injury and Repair Group, MRC Centre for Regenerative Medicine, The Chancellor's Building, University of Edinburgh, 49 Little France Crescent, Edinburgh EH16 4SB, Scotland, UK

E-mail: j.a.ross@ed.ac.uk

Key words: hepatocyte, stem cells, polarity, bile canaliculi, sandwich, tight junction, differentiation
The extensive in vitro replication capability of pluripotent stem cells has made them an attractive alternative cell source. Numerous studies show that embryonic stem cells (ESCs), induced pluripotent stem cells and adult stem cells can be differentiated towards the hepatic lineage (2-4).

Hepatocytes are used primarily in the pharmaceutical industry for screening new compounds. This screening helps to eliminate potentially toxic drugs at the preliminary stage, avoiding unanticipated effects at later stages of clinical trials and reducing the time and expense required for the commercialisation of new drugs. Due to their simplicity, commonly used materials, such as microsomal fractions, hepatocyte suspensions and short-term cultures, have their limitations for evaluating complex toxic reactions (5). A highly polarised hepatocyte model is necessary for evaluating hepatobiliary excretion and potential liver injury, and studying viral infections $(6,7)$.

Polarised hepatocytes have an asymmetric cell membrane characterised by the segregated expression of membrane proteins in different domains. Tight junctions are responsible for this segregation of apical and basolateral membrane domains. Apical poles of adjacent hepatocytes join to form a continuous channel, which is the bile canaliculi that harbours numerous transport proteins, such as multidrug resistance-associated protein 2 (MRP2), to excrete bile salts from the cell. The basal membrane domain (sinusoidal pole) is responsible for the uptake of recycled biliary salts and nutrients, and the secretion of various hepatic proteins into the blood circulation. Bile canaliculi formation is an important feature of polarised hepatocytes and can be observed microscopically as channels between adjacent hepatocytes. The formation of hepatic polarity in cultured cells can be assessed by the expression of the tight junction [zona occludin 1 (ZO-1)], localised expression of transport protein MRP2 to the bile canalicular side and by the excretion and localisation of traceable compounds, such as fluorescein, within bile canaliculi.

In the present study, human ESCs (hESCs) and mesenchymal stem cells (hMSCs) were differentiated to hepatocyte-like 
cells. These differentiated stem cells were examined for the expression of hepatic genes and functions. Hepatic polarisation, particularly the expression of tight junction protein ZO-1, the apical bile canalicular MRP2, bile canalicular protein dipeptidyl peptidase 4 (DPP4) and the excretion of fluorescein by these stem cell-derived hepatocytes was extensively evaluated and compared with that of the human foetal hepatocytes and HepG2 cells.

\section{Materials and methods}

hESC culture and hepatic differentiation (monolayer culture). The RCM1 hESC line was cultured and propagated in Matrigel-coated plates with mTeSR 1 medium (Stem Cell Technologies, Vancouver, BC, Canada) under feeder-free and serum-free conditions as previously described (8). Differentiation was initiated when the hESCs reached $\sim 30 \%$ confluency by replacing MTeSR-1 medium with priming medium [RPMI-1640 medium (Biosera, ZI du Bousquet, Boussens, France) containing 1X B27 supplement (Invitrogen Life Technologies, Carlsbad, CA, USA), $100 \mathrm{ng} / \mathrm{ml}$ Activin A (PeproTech, Rocky Hill, NJ, USA) and $50 \mathrm{ng} / \mathrm{ml}$ Wnt-3A (PeproTech)] for 3 days. Cells were subsequently maintained in differentiation medium [knockout Dulbecco's modified eagle medium (DMEM) (Invitrogen Life Technologies) containing $20 \%$ serum replacement, $1 \mathrm{mmol} / 1$ glutamine, $1 \%$ non-essential amino acids, $0.1 \mathrm{mmol} / 1 \beta$-mercaptoethanol (all from Invitrogen Life Technologies) and 1\% dimethyl sulfoxide (DMSO) (Sigma, St. Louis, MO, USA)] for 5 days. Finally, the cells were cultured in maturation medium [L15 medium containing $8.3 \%$ fetal bovine serum (FBS), $8.3 \%$ tryptose phosphate broth, $10 \mathrm{mmol} / 1$ hydrocortisone 21-hemisuccinate, $1 \mathrm{mmol} / 1$ insulin (all from Sigma), $2 \mathrm{mmol} / \mathrm{l}$ glutamine, $10 \mathrm{ng} / \mathrm{ml}$ hepatocyte growth factor (PeproTech) and $20 \mathrm{ng} / \mathrm{ml}$ oncostatin M (PeproTech)] for 9 days. Medium was changed every 2 days during differentiation.

Collagen sandwich culture of differentiated hESC (sandwich culture). Neutralised collagen solution $(100 \mu 1,1 \mathrm{mg} / \mathrm{ml}$ ) (Roche Diagnostics, Basel, Switzerland) was overlaid on hESCs that had differentiated for 12 days. Collagen was allowed to form a gel by incubating for $30 \mathrm{~min}$ at $37^{\circ} \mathrm{C}$ in a $\mathrm{CO}_{2}$ incubator. Sufficient medium was added to the wells and cells were subsequently cultured for 5 days.

Isolation and culture of hMSCs. Foetal pancreas samples from mid-trimester therapeutic terminations of pregnancy were obtained from the Royal Infirmary of Edinburgh with informed consent from patients and approval of the Local Research Ethics Committee. hMSCs were isolated as described previously (9). In brief, the pancreas was collected in ice-cold medium, finely sliced and incubated for 3 days undisturbed. Thereafter, plastic-adherent hMSCs were maintained in DMEM (Biosera) with 10\% FBS.

Differentiation of hMSCs to hepatocytes. Cells from passages 6-15 were used for hepatic differentiation. Hepatic differentiation was carried out as previously described (2). Induction was initiated when cells were $80 \%$ confluent by treating hMSCs with differentiation medium [DMEM containing $20 \mathrm{ng} / \mathrm{ml}$ hepatocyte growth factor, $10 \mathrm{ng} / \mathrm{ml}$ basic fibroblast growth factor (PeproTech) and nicotinamide $(0.61 \mathrm{~g} / 1)$ (Sigma)] for 7 days. Subsequently, cells were cultured in maturation medium [DMEM containing $20 \mathrm{ng} / \mathrm{ml}$ oncostatin M, $1 \mathrm{mmol} / \mathrm{l}$ dexamethasone (Sigma) and $1 \mathrm{X}$ Insulin-Transferrin-Selenium (Invitrogen Life Technologies)]. Cells were cultured for $\leq 41$ days in differentiation medium and the medium was changed twice/week.

Isolation and culture of foetal hepatocytes. Livers from mid-trimester therapeutic terminations of pregnancy were obtained from the Royal Infirmary of Edinburgh with informed consent from patients and approval of the Local Research Ethics Committee. Foetal hepatocytes were isolated as described previously (10). In brief, livers were collected in ice-cold Williams' E medium (Invitrogen Life Technologies), dissected free of fibrous material, finely sliced and washed in Hanks' balanced salt solution (HBSS) to remove the red blood cells. Tissue fragments were digested with $0.1 \%$ collagenase type II (Worthington Biochemical Corporation, Lakewood, NJ, USA) in HBSS. Digestion was stopped by the addition of DMEM with 10\% FBS. Cells were centrifuged and resuspended in Williams' E medium supplemented with $10 \% \mathrm{FBS}$, $50 \mathrm{U} / \mathrm{ml}$ penicillin, $50 \mathrm{mg} / \mathrm{ml}$ streptomycin, $2 \mathrm{mmol} / 1$ glutamine, 1X Insulin-Transferrin-Selenium (all from Invitrogen Life Technologies) and $10^{-7} \mathrm{M}$ dexamethasone. Viability was determined with $0.2 \%$ trypan blue using a Neubauer hemocytometer. Cells $\left(2.7 \times 10^{6}\right.$ cells $\left./ \mathrm{cm}^{2}\right)$ were cultured at $37^{\circ} \mathrm{C}$ in $5 \% \mathrm{CO}_{2}$ on collagen-coated plates [for coating plates, $250 \mu \mathrm{l}$ of collagen solution (type I collagen, $1.5 \mathrm{mg} / \mathrm{ml}$ ) was added to the wells, excess solution removed and plates incubated at $37^{\circ} \mathrm{C}$ for $\left.1 \mathrm{~h}\right]$.

Estimation of secreted proteins by enzyme-linked immunosorbent assay. Cells were cultured in 12-well plates in $500 \mu \mathrm{l}$ of appropriate media and the supernatant was collected for the protein assay after $24 \mathrm{~h}$. Hepatic proteins were measured using sandwich enzyme-linked immunosorbent assays (ELISAs), as described by the manufacturer (Dako, Glostrup, Denmark). High-binding EIA plates were coated with a rabbit anti-human antibody (Dako) specific for the protein of interest (Dako) overnight at $4^{\circ} \mathrm{C}$. Sample supernatants were diluted 1:10 and added to 96 -well plates in triplicate. Plates were subsequently incubated for $2 \mathrm{~h}$ at room temperature. Peroxidase-conjugated rabbit anti-human antibody directed against the appropriate protein (Dako) was added and the plates were incubated for $1 \mathrm{~h}$ at room temperature. The substrate $o$-phenylenediamine was added and the reaction was stopped with $0.5 \mathrm{M}$ sulphuric acid. The plates were read at $490 \mathrm{~nm}$ with a reference wavelength of $630 \mathrm{~nm}$ using MRX II Endpoint software (Dynex Technologies,Chantilly, VA, USA). To normalise the ELISA results, cells were lysed and the total protein was estimated using the DC protein assay kit (Bio-Rad, Hercules, CA, USA).

Immunostaining and flow cytometry. For immunostaining, cells were fixed in $4 \%$ paraformaldehyde for $10 \mathrm{~min}$ at room temperature and washed with phosphate-buffered saline. After blocking with $2 \%$ appropriate serum, cells were incubated with the primary antibody at $4^{\circ} \mathrm{C}$ overnight followed by incubation with the appropriate secondary antibody for 
Table I. Antibodies and the dilutions used.

\begin{tabular}{|c|c|c|c|c|}
\hline Antibody & Catalogue no. & Supplier & Country & Dilution \\
\hline $\begin{array}{l}\text { Alexa Fluor } 594 \mathrm{~F}(\mathrm{ab}) 2 \text { fragment } \\
\text { of goat anti-mouse } \operatorname{IgG}(\mathrm{H}+\mathrm{L})\end{array}$ & A11020 & $\begin{array}{l}\text { Molecular Probes/Invitrogen } \\
\text { Life Technologies }\end{array}$ & USA & $1: 100$ \\
\hline Alexa Fluor 594 goat anti-rabbit IgG & A11037 & $\begin{array}{l}\text { Molecular Probes/ Invitrogen } \\
\text { Life Technologies }\end{array}$ & USA & $1: 100$ \\
\hline Anti-human albumin FITC conjugated & CLFAG2140 & Cedarlane & Canada & $1: 50$ \\
\hline Anti-mouse IgG FITC conjugated & F2883 & Sigma & USA & $1: 50$ \\
\hline $\begin{array}{l}\text { Monoclonal anti-human hepatocyte } \\
\text { specific antigen }\end{array}$ & NCL-HSA & Novocastra/Leica & Germany & $1: 20$ \\
\hline Monoclonal mouse anti-human CK18 & M7010 & Dako & Denmark & $1: 20$ \\
\hline Mouse anti-CD13 & MCA1270 & ABD Serotec & UK & $1: 100$ \\
\hline Mouse anti-human CD105 & MCA1557 & ABD Serotec & UK & $1: 50$ \\
\hline Mouse anti-human CD117 & MCA1841 & ABD Serotec & UK & $1: 20$ \\
\hline Mouse anti-human CD29 & MCA1949GA & ABD Serotec & UK & $1: 100$ \\
\hline Mouse anti-human CD31 (PECAM-1) & MCA1738 & ABD Serotec & UK & $1: 100$ \\
\hline Mouse anti-human CD34 & MCA547G & ABD Serotec & UK & $1: 200$ \\
\hline Mouse anti-human CD44 & MCA89 & ABD Serotec & UK & $1: 20$ \\
\hline Mouse anti-human CD45 & MCA87GA & ABD Serotec & UK & $1: 50$ \\
\hline Mouse anti-human CD49b & MCA743GA & ABD Serotec & UK & $1: 100$ \\
\hline Mouse anti-human CD54 & MCA1615GA & ABD Serotec & UK & $1: 100$ \\
\hline Mouse anti-human CD90 & MCA90 & ABD Serotec & UK & $1: 50$ \\
\hline Mouse anti-human DPP4 (CD26) & 555435 & BD Pharmingen & USA & $1: 100$ \\
\hline Mouse IgG1-negative control & MCA928 & ABD Serotec & UK & $1: 100$ \\
\hline Mouse IgG2a-negative control & MCA929 & ABD Serotec & UK & $1: 100$ \\
\hline Mouse monoclonal antibody to MRP2 & ab3373 & Abcam & UK & $1: 250$ \\
\hline Rabbit polyclonal to ZO-1 & ab59720 & Abcam & UK & $1: 25$ \\
\hline
\end{tabular}

IgG, immunoglobulin G; FITC, fluorescein isothiocyanate; CK18, cytokeratin 18; CD, cluster of differentiation; DPP4, dipeptidyl peptidase 4; MRP2, multidrug resistance-associated protein 2; ZO-1, zona occludin 1.

$1 \mathrm{~h}$ at room temperature. Nuclei were counterstained with 4',6-diamidino-2-phenylindole. For flow cytometry, cells were harvested and incubated in blocking buffer containing $2 \%$ rabbit serum for $30 \mathrm{~min}$ followed by incubation for $30 \mathrm{~min}$ with the primary antibody, according to the manufacturer's instructions. The cells were counterstained with rabbit anti-mouse secondary antibody for $30 \mathrm{~min}$ and were analysed in a Beckman Coulter EPICS flow cytometer (Brea, CA, USA) after washing. Primary antibodies were replaced with the corresponding immunoglobulin $\mathrm{G}$ antibodies for the control conditions. Antibodies used for immunostaining and flow cytometry are listed in Table I.

Excretion of fluorescein diacetate. The functional reconstitution of bile canaliculi was assessed by the localisation of secreted fluorescein within the bile canaliculi. Cells were treated with fluorescein diacetate $(10 \mu \mathrm{g} / \mathrm{ml})$ (Sigma) for 10 min and immediately observed by fluorescence microscopy (DM IRB; Leica, Mannheim, Germany) to visualise fluorescein localisation.

RNA isolation and reverse transcription-polymerase chain reaction $(R T-P C R)$. Total RNA was isolated using the TRI reagent (Sigma) following the manufacturer's instructions.
cDNA was synthesised using $1 \mathrm{mg}$ total RNA with RT in a $20 \mathrm{ml}$ volume following the manufacturer's instructions (Promega Corporation, Madison, WI, USA). The PCR was performed using the primer sequences and PCR conditions provided in Table II for 35 cycles. PCR products were analysed on a $2 \%$ agarose gel and the product size was estimated using a 100-bp DNA ladder.

Quantitative PCR ( $P$ PCR) analysis. qPCR was performed according to the TaqMan ${ }^{\circledR}$ Fast Universal PCR Master mix instructions. The reaction mixture was prepared and PCR amplification was performed using the TaqMan ${ }^{\circledR}$ Gene Expression Assay mix for hepatocyte nuclear factor $4 \alpha$ (HNF4 $\alpha$ ), cytochrome P450 2D6 (CYP2D6), $\beta_{2}$-macroglobulin and $\beta$-actin. The optimal baseline and threshold for each gene was set appropriately and the cycle threshold $\left(\mathrm{C}_{\mathrm{T}}\right)$ value was determined. The $\mathrm{C}_{\mathrm{T}}$ value of each sample was analysed and the sample group $\mathrm{C}_{\mathrm{T}}$ mean and standard deviation were calculated. $\beta_{2}$-macroglobulin was considered as the reference gene $\left(\beta_{2}\right.$-macroglobulin showed the same level of expression in all the samples: $\mathrm{C}_{\mathrm{T}}$ standard deviation $<1$ ). The gene transcripts were quantified by $\Delta \Delta \mathrm{C}_{\mathrm{T}}$ analysis, normalised with adult human hepatocytes and the results are expressed as fold change. 
Table II. Primer sequence, product length and annealing temperature.

\begin{tabular}{|c|c|c|c|}
\hline Gene & Primer sequence & Product length, bp & Annealing temperature, ${ }^{\circ} \mathrm{C}$ \\
\hline$A L B$ & $\begin{array}{l}\text { 5'-TGAGAAAACGCCAGTAAGTGAC-3' } \\
\text { 5'-TGCGAAATCATCCATAACAGC-3' }\end{array}$ & 265 & 49 \\
\hline$C P S$ & $\begin{array}{l}\text { 5'-TGAGGGATGCTGACCCCATT-3' } \\
\text { 5'-CATTGTTGGCGTTGAGCCAG-3' }\end{array}$ & 255 & 53 \\
\hline CYP1A1 & $\begin{array}{l}\text { 5'-TTCGTCCCCTTCACCATC-3' } \\
\text { 5'-CTGAATCCACCCGTTGC-3' }\end{array}$ & 302 & 49 \\
\hline$C K 18$ & $\begin{array}{l}\text { 5'-CCCGCTACGCCCTACAGAT-3' } \\
\text { 5'-ACCACTTTGCCATCCACTATCC-3' }\end{array}$ & 271 & 53 \\
\hline CK19 & $\begin{array}{l}\text { 5'-TCCAGATGAGCAGGTCCGAGGTTA-3' } \\
\text { 5'-GCTGCGGTAGGTGGCAATCTCC-3' }\end{array}$ & 281 & 57 \\
\hline$H N F 4 \alpha$ & $\begin{array}{l}\text { 5'-GCCTACCTCAAAGCCATCAT-3' } \\
\text { 5'-GACCCTCCCAGCAGCATCTC-3' }\end{array}$ & 275 & 53 \\
\hline$M R P 2$ & $\begin{array}{l}\text { 5'-ACAGAGGCTGGTGGCAACC-3' } \\
\text { 5'-ACCATTACCTTGTCACTGTCCATGA-3' }\end{array}$ & 227 & 54 \\
\hline$T D O$ & $\begin{array}{l}\text { 5'-GGTTTAGAGCCACATGGATT-3' } \\
\text { 5'-ACAGTTGATCGCAGGTAGTG-3' }\end{array}$ & 425 & 62 \\
\hline$A F P$ & $\begin{array}{l}\text { 5'-GCTTGGTGGTGGATGAAACA-3' } \\
\text { 5'-TCCTCTGTTATTTGTGGCTTTTG-3' }\end{array}$ & 157 & 50 \\
\hline$A C T B$ & $\begin{array}{l}\text { 5'-GCACTCTTCCAGCCTTTC-3' } \\
\text { 5'-AGAAAGGGTGTAACGCAACTAAG-3' }\end{array}$ & 385 & 51 \\
\hline
\end{tabular}

bp, basepair; $A L B$, albumin; $C P S$, carbomyl phosphate synthetase 1; CYP1A1, cytochrome P450 1A1; CK18, cytokeratin 18; HNF4 $\alpha$, hepatocyte nuclear factor $4 \alpha ; M R P 2$, multidrug resistance-associated protein 2; TDO, tryptophan 2,3-dioxygenase; $A F P$, $\alpha$-fetoprotein; $A C T B$, $\beta$-actin.

Periodic-acid Schiff (PAS) staining. Culture dishes containing cells were fixed in $4 \%$ formaldehyde and permeabilised with $0.1 \%$ Triton X-100 for $10 \mathrm{~min}$. Samples were oxidised in $2 \%$ periodic acid for $5 \mathrm{~min}$, treated with Schiff's reagent for $15 \mathrm{~min}$ and rinsed in deionised water for 5 to $10 \mathrm{~min}$. Samples were counterstained with Mayer's haematoxylin for $20 \mathrm{sec}$, rinsed and assessed by light microscopy.

Indocyanin uptake. To determine the cellular uptake of indocyanin green (ICG; Sigma), $1 \mathrm{mg} / \mathrm{ml}$ of ICG in DMEM containing $10 \%$ FBS was added to cell cultures and incubated at $37^{\circ} \mathrm{C}$ for $15 \mathrm{~min}$. Cells were subsequently rinsed and cellular uptake of ICG was examined by microscopy.

Statistical analysis. Data obtained from 3 independent experiments with 3 replicates were evaluated by Student's t-test. Data are expressed as mean \pm standard deviation and $\mathrm{P}<0.05$ was considered to indicate a statistically significant difference.

\section{Results}

Characterisation of hMSCs. MSCs were isolated from human foetal pancreas by plastic adherence and were characterised for the expression of essential MSC markers by flow cytometry $(11,12)$. hMSCs were positive for cluster of differentiation 90 (CD90) $(90 \pm 1 \%)$, CD105 (56 $\pm 12 \%)$, CD49b

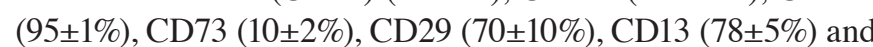
CD44 $(96 \pm 1 \%)$ and were negative for CD34, CD117, CD31 and CD45 (Fig. 1).
Differentiation of hMSCs to hepatocytes. Although MSCs are highly proliferative, their growth slows during differentiation. During the initial phase of differentiation (the first week post-induction), the fibroblast spindle morphology of hMSCs became more broad and elongated. During the maturation phase, in the presence of oncostatin $\mathrm{M}$ and dexamethasone, a retraction of elongated ends was observed and the cells developed a cubical morphology by the second week post-induction. Following prolonged culture, the hepatic morphology further matured with a polygonal shape and the cells became much more compact (Fig. 2A).

The expression of hepatic markers by hMSC-derived hepatocytes (mDHs) was analysed. $\mathrm{mDH}$ were positive for albumin, cytokeratin 18 (CK18) and hepatocyte-specific antigen, confirming their hepatic differentiation (Fig. 2B). Furthermore, flow cytometry showed that $86 \pm 4 \%$ of MSC-derived hepatocytes were positive for albumin, confirming the efficient hepatic differentiation of hMSCs (Fig. 2C).

The glycogen storage function was also examined in $\mathrm{mDHs}$ using PAS staining. mDHs exhibited evident glycogen storage (Fig. 2D), a function of the liver in carbohydrate metabolism. As hepatocytes are the major cells involved in xenobiotic metabolism, the uptake of xenobiotic compounds by $\mathrm{mDHs}$ was tested using ICG. MSC-derived hepatocytes exhibited evident indocyanin uptake (Fig. 2E), confirming their ability to uptake xenobiotic compounds. RT-PCR analysis confirmed that differentiated hMSCs expressed various hepatic genes, including $\alpha$-fetoprotein (foetal form of serum albumin), albumin (a serum protein produced by hepatocytes), CK18 (hepatic cytoskeleton protein), carbomyl phosphate synthase 

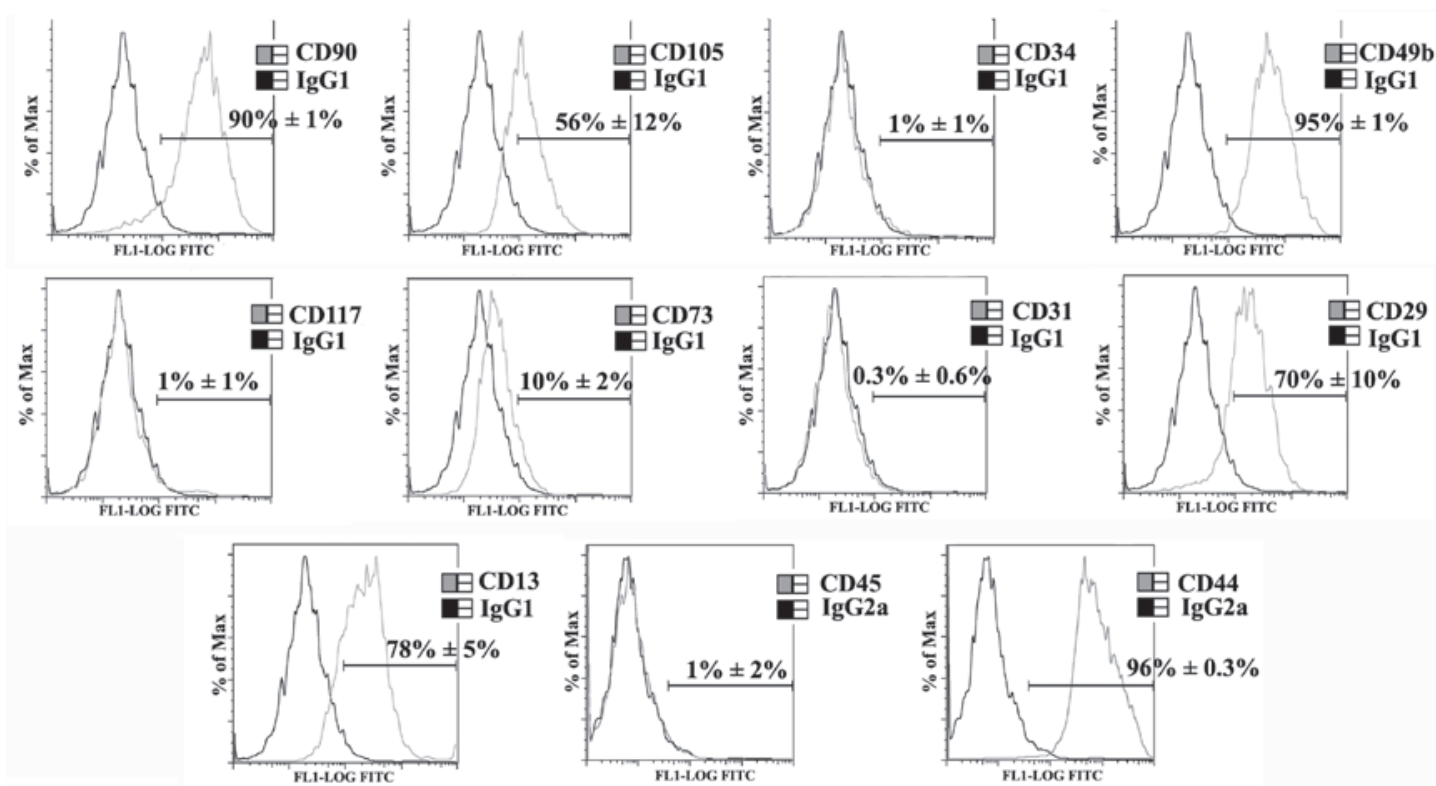

Figure 1. Characterisation of mesenchymal stem cells (MSCs). MSCs isolated from human foetal pancreas were characterised by flow cytometry. The black and gray histograms represent isotype control and test, respectively. Inset value denotes the percentage of the positive population. MSCs were positive for

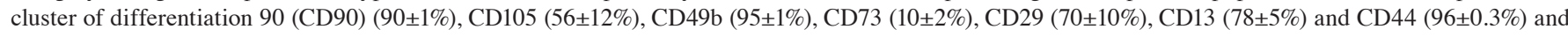

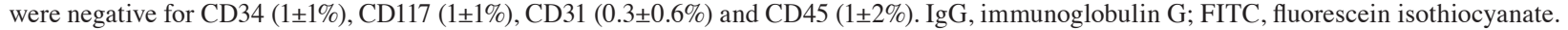

A Day 0

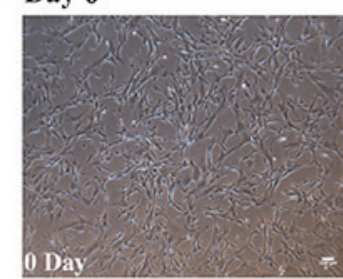

B ALB

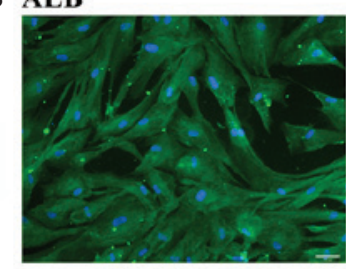

C

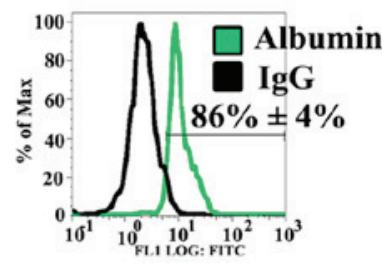

Day 7

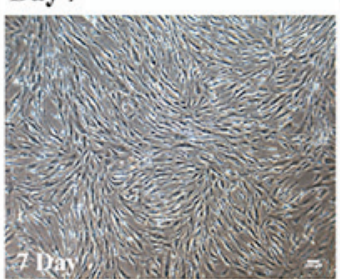

CK18

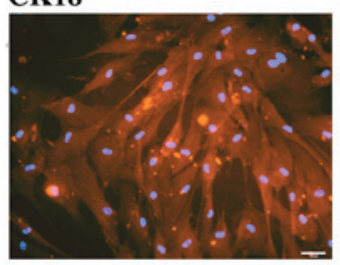

D

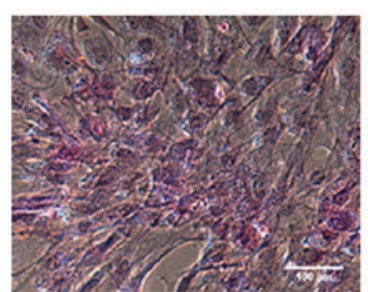

Day 21

HSA
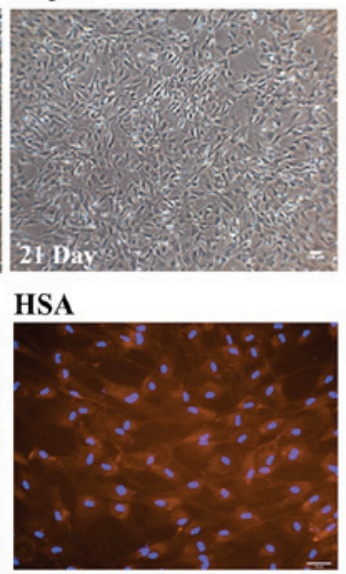

$\mathbf{E}$

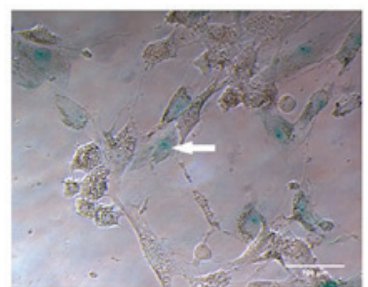

Day 28

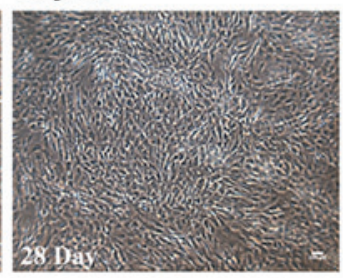

CD90

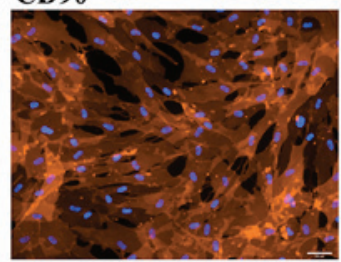

Day 41

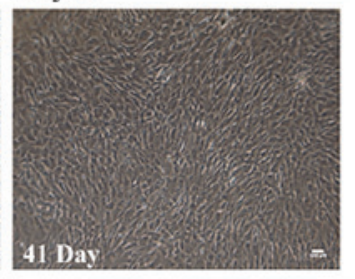

IgG

$\mathbf{F}$

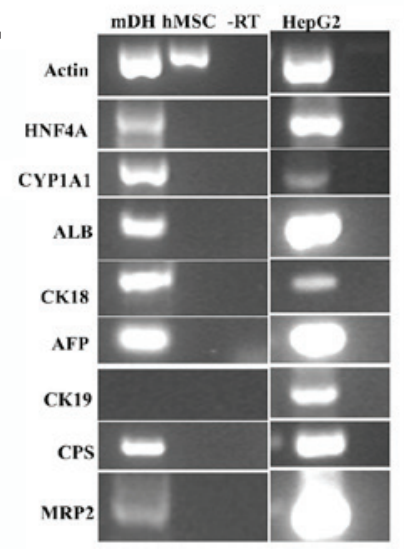

Figure 2. Characterisation of human mesenchymal stem cell (hMSC)-derived hepatocytes. (A) Phase contrast images showing the change in morphology during differentiation. (B) Immunostaining showing the expression of ALB, CK18, hepatocyte-specific antigen (HSA) and CD90 on day 41 . Immunoglobulin G (IgG) represents the negative control. (C) Flow cytometry showing the expression of albumin on day 41. Bright field image showing (D) positive periodic-acid Schiff staining (pink) and (E) indocyanin green uptake (arrowhead point cells showing indocyanin uptake) on day 41 . In all the images, the scale bar denotes $100 \mu \mathrm{m}$. (F) Reverse transcription-polymerase chain reaction showing the expression of hepatic genes on day 41 . Actin, $\beta$-actin; HNF $4 \alpha$, hepatocyte nuclear factor $4 \alpha$; CYP1A1, cytochrome P450 1A1; ALB, albumin; CK18, cytokeratin 18; AFP, $\alpha$-fetoprotein; CK19, cytokeratin 19; CPS, carbomyl phosphate synthetase 1; MRP2, multidrug resistance-associated protein 2; $\mathrm{mDH}$, hMSC-derived hepatocytes; hMSC, undifferentiated hMSCs; -RT, negative reverse transcription; HepG2, HepG2 cells; FITC, fluorescein isothiocyanate. 
A
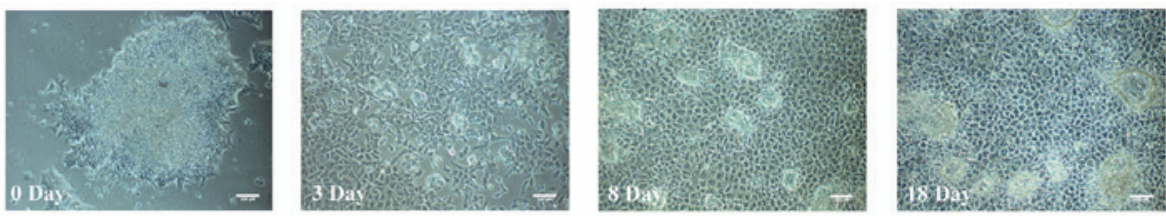

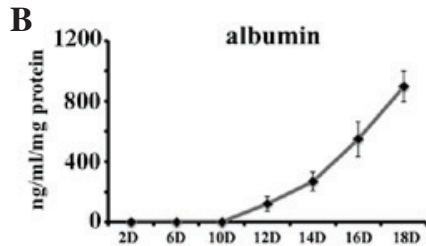

C

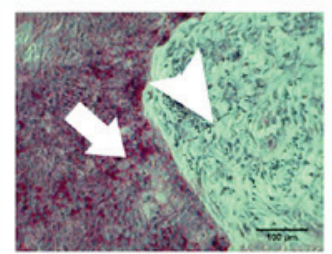

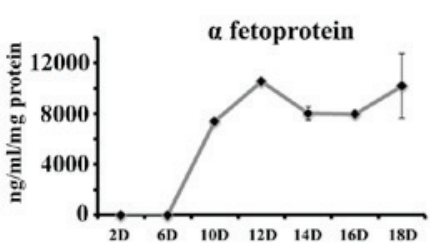

D

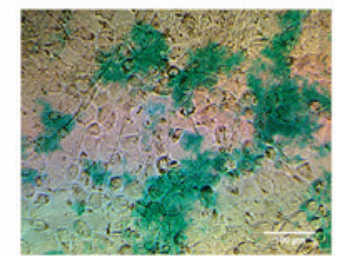

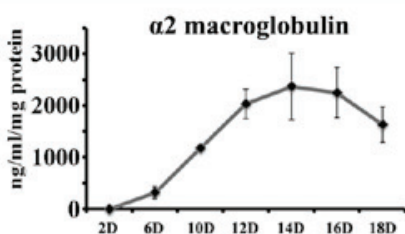

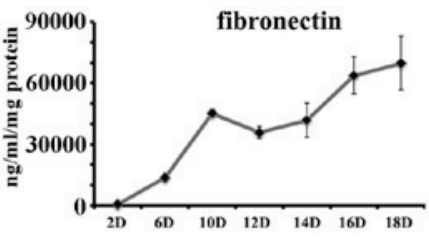

$\mathbf{E}$

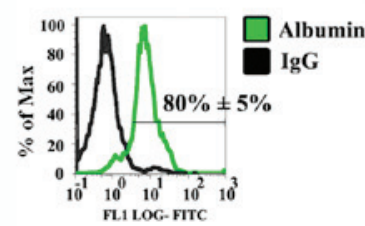

F

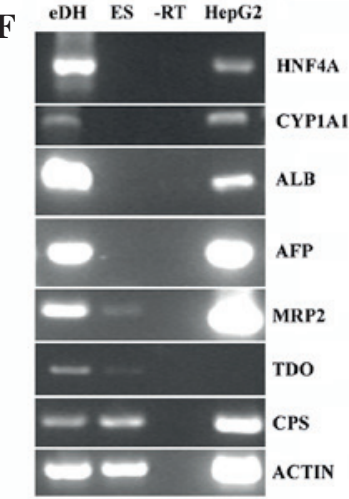

Figure 3. Characterisation of embryonic stem cell-derived hepatocytes. (A) Phase contrast images showing the change in morphology during differentiation. (B) Human embryonic stem cell (hESC)-derived hepatocytes (eDHs) showing the secretion of hepatic proteins. The x-axis represents the day of differentiation and the $\mathrm{y}$-axis represents protein concentration (ng/ml/mg of total protein). (C) Bright field image showing periodic-acid Schiff stained eDHs (arrow with the tail points to eDHs and arrow without the tail points to differentiation resistant hESCs) on day 17. (D) Bright field image showing indocyanin green uptake on day 17. In all the images, the scale bar denotes $100 \mu \mathrm{m}$. (E) Flow cytometry showing the expression of albumin on day 17. (F) Reverse transcription-polymerase chain reaction showing the expression of hepatic genes on day 17. HNF4 $\alpha$, hepatocyte nuclear factor 4 $\alpha$; CYP1A1, cytochrome P450 1A1; ALB, albumin; AFP, $\alpha$-fetoprotein; MRP2, multidrug resistance-associated protein 2; TDO, tryptophan 2,3-dioxygenase; CPS, carbomyl phosphate synthetase 1; Actin, $\beta$-actin; eDH, hESC-derived hepatocytes; EC, undifferentiated hESCs; -RT, negative reverse transcription; HepG2, HepG2 cells; IgG, immunoglobulin G; FITC, fluorescein isothiocyanate.

(an enzyme of urea cycle), cytochrome P450 1A1 (CYP1A1; an enzyme involved in xenobiotic metabolism), HNF4 $\alpha$ (hepatic transcription factor) and MRP2 (export protein) (Fig. 2F).

Differentiation of hESCs to hepatocytes. For differentiation, hESCs routinely cultured without feeder cells were treated with Activin A and Wnt-3A for 3 days. The cells proliferated extensively and reached a confluency of $80-90 \%$ during the initial 3 days (priming stage). Furthermore, the shape of the cells became spiky and triangular during this stage. The cells were subsequently changed to SR-DMSO differentiation medium and cultured for 5 days. Cell death was observed during the initial $24 \mathrm{~h}$ in differentiation medium, although cell death was lower in cultures with higher confluency and better cell-cell contacts. Cells in differentiation medium gradually exhibited a morphological change from a triangular to a polygonal outline (Fig. 3A). Medium was finally changed to maturation medium and the cells were cultured for 10 days, during which they exhibited the characteristic hepatocyte morphology; polygonal shape with large nuclei.

One of the functions of hepatocytes in the liver is the secretion of plasma proteins, such as albumin (essential for maintaining blood osmolarity), $\alpha$-fetoprotein (the major protein of foetal serum), $\alpha 2$-macroglobulin (a protease inhibitor) and fibronectin (an extracellular protein capable of binding to receptor proteins). To examine the secretion of these hepatic proteins by hESC-derived hepatocytes (eDHs), the culture medium from these cells was analysed by ELISA. The secretion of plasma proteins by eDHs significantly increased at different stages of differentiation, and this secretion peaked during the later differentiation stage (Fig. 3B).

PAS staining revealed evident glycogen storage in eDHs (Fig. 3C). eDHs also exhibited evident indocyanin uptake, confirming the generation of functional hepatocytes (Fig. 3D). Flow cytometry showed that $80 \pm 5 \%$ of eDHs were positive for albumin, confirming the efficient hepatic differentiation of hESCs (Fig. 3E). Furthermore, PCR analysis revealed that eDHs expressed HNF4 $\alpha$ (a hepatic transcription factor), CYP1A1 (an enzyme involved in xenobiotic metabolism), albumin (a serum protein produced by hepatocytes), $\alpha$-fetoprotein (a major foetal serum protein), MRP2 (also known as canalicular multispecific organic anion transporter 1 or ATP-binding cassette subfamily C member-ABCC2), tryptophan 2,3-dioxygenase (an enzyme involved in amino acid metabolism) and carbomyl phosphate synthase (an enzyme involved in the urea cycle) (Fig. 3F).

Polarisation of stem cell-derived hepatocytes. Polarisation of ESC-derived hepatocytes was evaluated by the expression of the tight junction protein $\mathrm{ZO}-1$ and the apical export protein MRP2 and bile canalicular protein DPP4. The functional ability of formed bile canaliculi was further evaluated by 

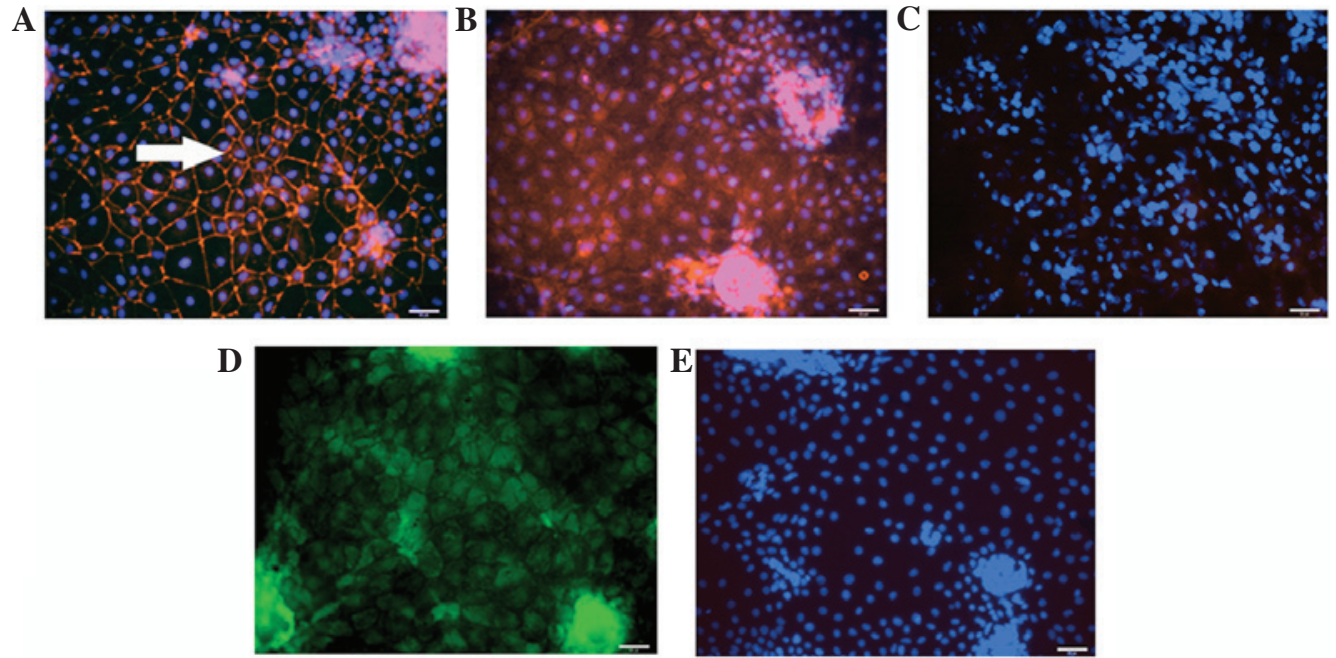

Figure 4. Polarisation of differentiated human embryonic stem cell (hESC). Fluorescence images showing the expression of (A) zona occludin 1 (ZO-1), (B) multidrug resistance-associated protein 2, (C) dipeptidyl peptidase 4 and (D) the excretion of fluorescein by hESC-derived hepatocytes on day 17. (E) The negative control. The arrowhead points to the localised expression of ZO-1. Scale bar denotes $50 \mu \mathrm{m}$.
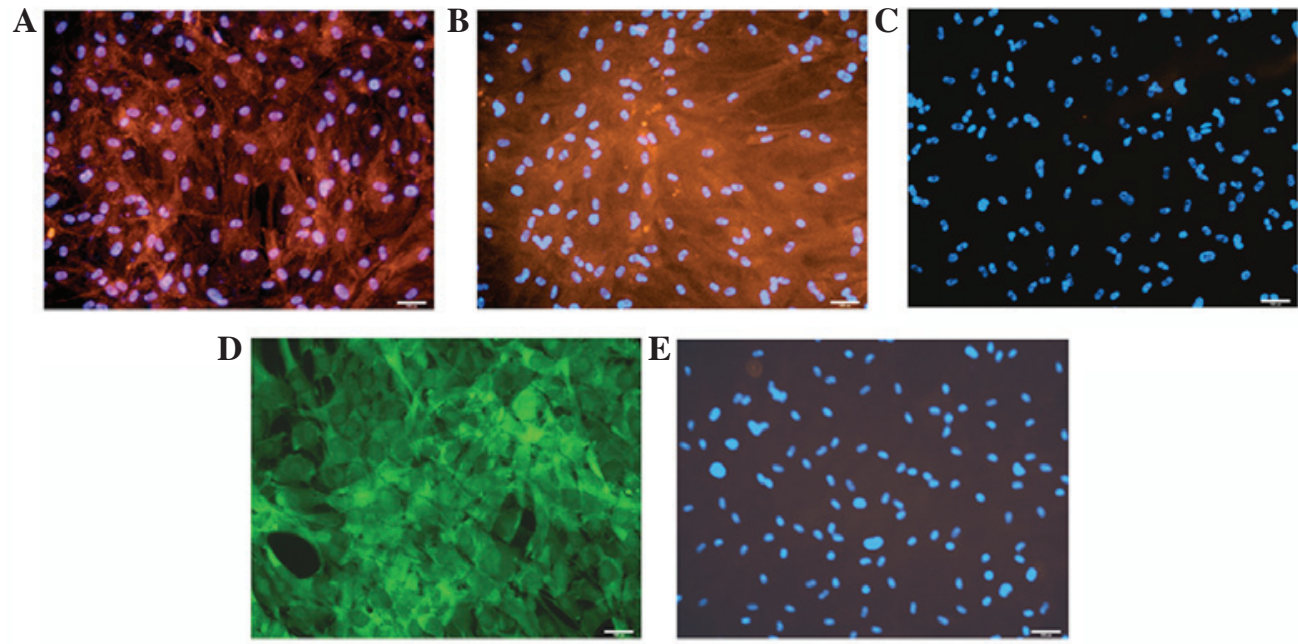

Figure 5. Polarisation of differentiated human mesenchymal stem cell (hMSC). Fluorescence images showing the expression of (A) zona occludin 1, (B) multidrug resistance-associated protein 2, (C) dipeptidyl peptidase 4 and (D) the excretion of fluorescein by hMSC-derived hepatocytes on day 41 . (E) The negative control. Scale bar denotes $100 \mu \mathrm{m}$.

accumulation of fluorescein. eDHs cultured as a monolayer expressed the tight junction protein ZO-1 (Fig. 4A), however, they did not show localised expression of MRP2 (Fig. 4B) and DPP4 (Fig. 4C) at their apical sides. Additionally, fluorescein accumulation was not visible in these cells (Fig. 4D).

Although mDHs showed the expression of tight junction protein ZO-1, the expression was not localised to the cell borders (Fig. 5A). Similarly, MRP2 expression was not localised to the apical side of the cell (Fig. 5B) and the DPP4 expression was not observed (Fig. 5C). mDHs were also not able to localise fluorescein (Fig. 5D).

Foetal hepatocytes showed expression of tight junctions at cell borders (Fig. 6A) and localised expression of MRP2 (Fig. 6B) and DPP4 (Fig. 6C) at the apical side of the cell. In addition, foetal hepatocytes showed fluorescein excretion localised to bile canaliculi (Fig. 6D).

In the HepG2 hepatic cell line, expression of the tight junction protein ZO-1 was not uniform (Fig. 7A) and MRP2
(Fig. 7B) and DPP4 (Fig. 7C) expression was confined between a few cells.

Secretion of hepatic proteins by stem cell-derived hepatocytes. The functionality of eDHs, $\mathrm{mDHs}$, human foetal hepatocytes and HepG2 cells were compared by analysing the secretion of hepatic proteins (albumin, prealbumin, $\alpha$-fetoprotein, fibrinogen, haptoglobulin, $\alpha 2$-macroglobulin and fibronectin) by ELISA (Fig. 8). The secretion of mature hepatic proteins albumin, fibrinogen and haptoglobulin was higher in foetal hepatocytes, while $\alpha 2$-macroglobulin secretion was higher in HepG2 cells. Higher secretion of premature hepatic proteins, prealbumin and $\alpha$-fetoprotein was observed in eDHs. MSC-derived hepatocytes showed extremely low expression of all hepatic proteins.

Expression of hepatic genes by stem cell-derived hepatocytes. The expression of hepatic genes (MRP2, HNF4 $\alpha$ and 

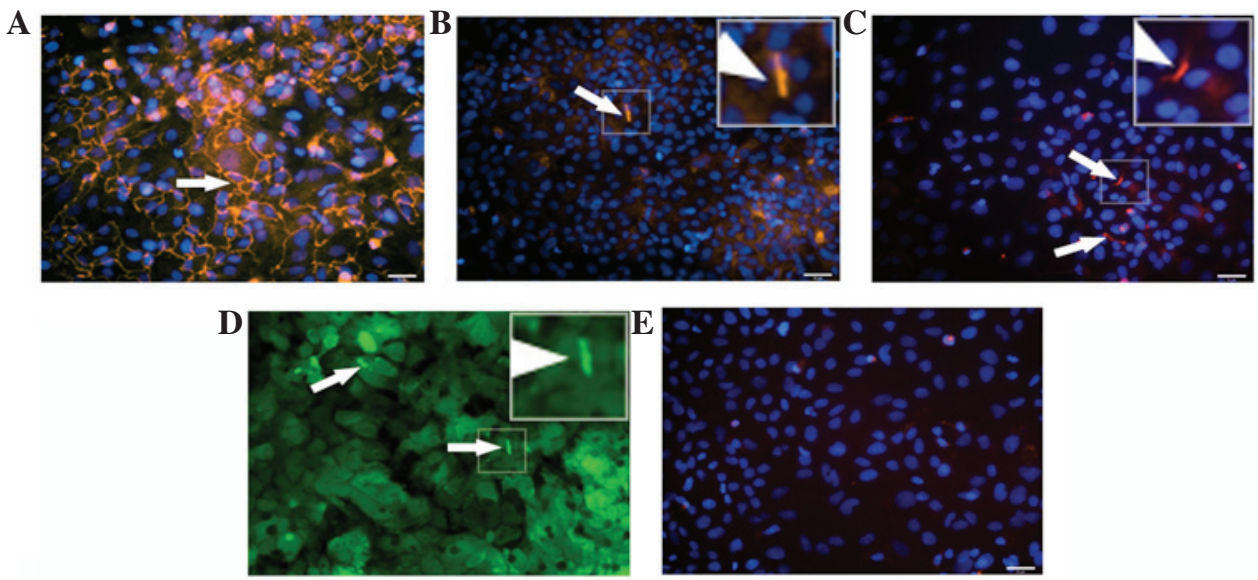

Figure 6. Polarisation of human foetal hepatocytes. Representative fluorescence images showing the expression of (A) zona occludin 1, (B) multidrug resistance-associated protein 2, (C) dipeptidyl peptidase 4 and (D) the excretion of fluorescein by human foetal hepatocytes on day 3. (E) The negative control. The arrowhead points to the localised expression of corresponding protein/fluorescein localization. Scale bar denotes $50 \mu \mathrm{m}$. Top right inset is the zoomed view of the marked area.
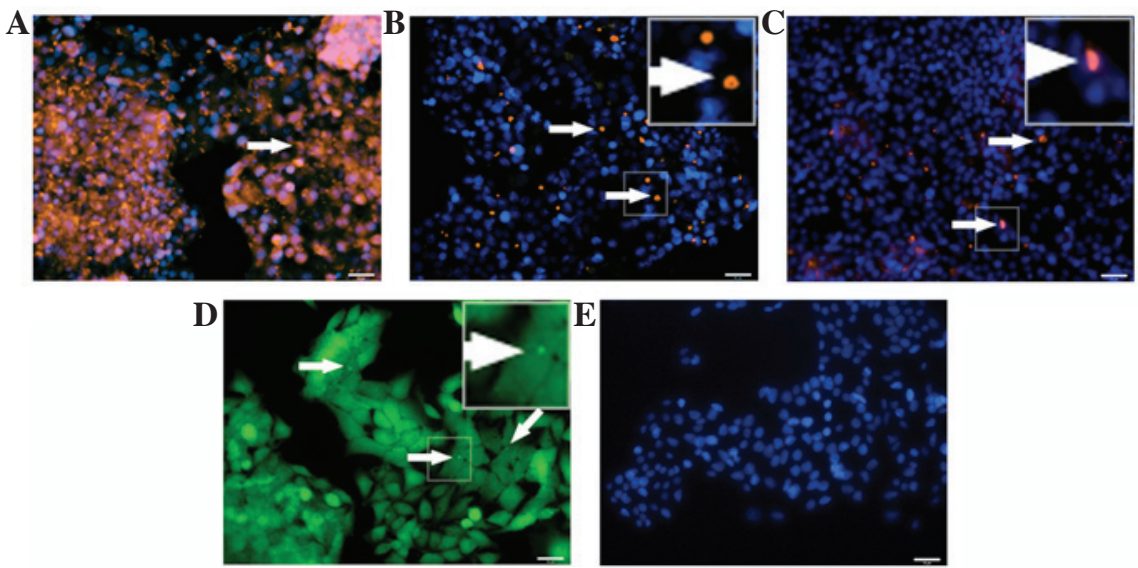

Figure 7. Polarisation of HepG2 cells. Representative fluorescence images showing the expression of (A) zona occludin 1, (B) multidrug resistance-associated protein 2, (C) dipeptidyl peptidase 4 and (D) the excretion of fluorescein by HepG2 cells. (E) The negative control. The arrowhead points to the localised expression of corresponding protein/fluorescein localization. Scale bar denotes $50 \mu \mathrm{m}$. Top right inset is the zoomed view of the marked area.
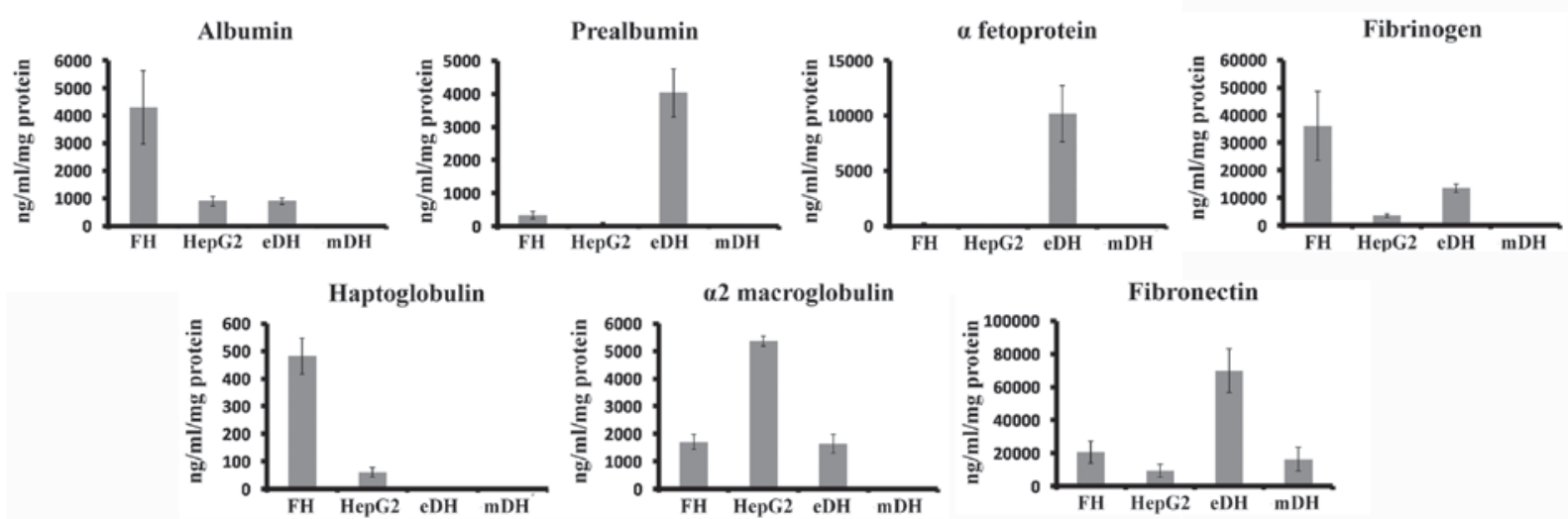

Figure 8. Secretion of hepatic proteins by stem cell-derived hepatocytes. ELISA results showing the secretion of hepatic proteins. The x-axis represents the cell type. The y-axis represents the secreted protein concentration (ng/ml/mg protein). FH, foetal hepatocyte; HepG2, HepG2 cell line; eDH, hESC-derived hepatocytes; $\mathrm{mDH}$, hMSC-derived hepatocytes.

CYP1A1) by MSC-derived hepatocytes, eDHs, human foetal hepatocytes and HepG2 cells were examined by RT-PCR (Fig. 9A).
In order to validate the RT-PCR result for $\mathrm{HNF} 4 \alpha$ and CYP enzyme expression, qPCR analysis was performed. qPCR analysis confirmed that HNF4 $\alpha$ expression was in 


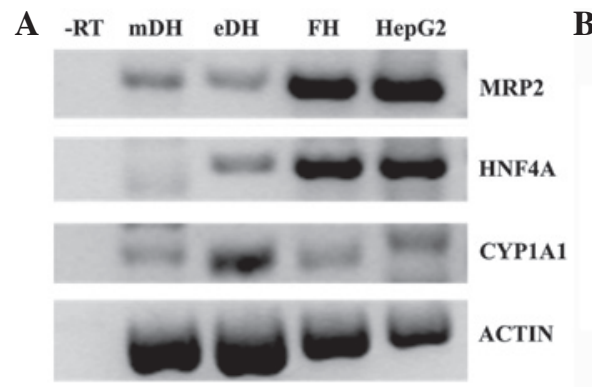

B

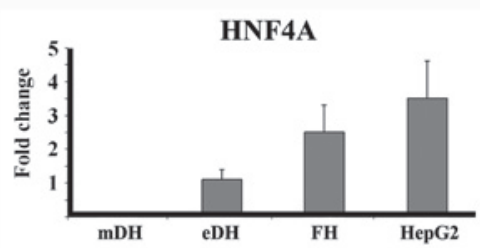

C

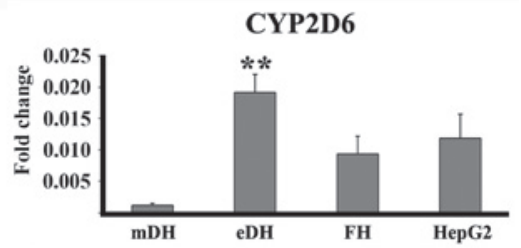

Figure 9. Expression of hepatic genes by stem cell-derived hepatocytes. (A) Reverse transcription-polymerase chain reaction (RT-PCR) showing the expression of hepatic genes in different cell types. Quantitative PCR (qPCR) analysis showing the relative expression of (B) HNF4 $\alpha$ and (C) CYP2D6 in the different cell types. ${ }^{* * *} \mathrm{P}<0.05$. Actin, $\beta$-actin; CYP1A1, cytochrome P450 1A1; CYP2D6, cytochrome P450 2D6; HNF4 $\alpha$, hepatocyte nuclear factor 4 $\alpha ; M R P 2$, multidrug resistance-associated protein 2; -RT, negative reverse transcription control; $\mathrm{mDH}$, MSC-derived hepatocytes; eDH, hESC-derived hepatocytes; FH, foetal hepatocyte; HepG2, HepG2 cells.
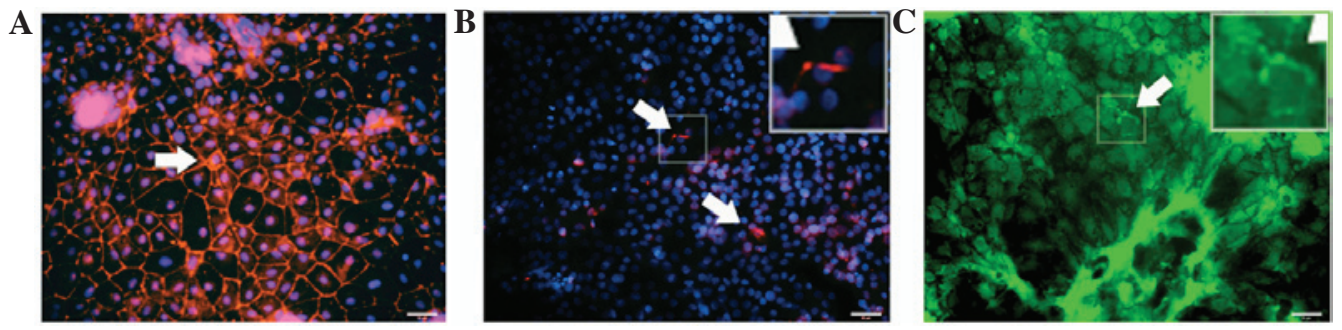

Figure 10. Polarisation of sandwich-cultured embryonic stem cell-derived hepatocytes. Fluorescence images showing the expression of (A) zona occludin 1, (B) dipeptidyl peptidase 4 and (C) the excretion of fluroescein by sandwich-cultured embryonic stem cell-derived hepatocytes on day 17. The arrowhead points to the localised expression of the corresponding protein/fluorescein localization. Scale bar denotes $50 \mu \mathrm{m}$. Top right inset is the zoomed view of the marked area.

the order: HepG2 cells $>$ foetal hepatocytes $>\mathrm{eDHs}>\mathrm{mDHs}$ (Fig. 9B). qPCR analysis also confirmed the higher expression of CYP2D6 by eDHs compared to the HepG2 cells and foetal hepatocytes (Fig. 9C).

Effect of extracellular matrix in polarising eDHs. To evaluate the effect of extracellular matrix in polarising eDHs, the polarity of sandwich-cultured eDHs was assessed by the expression of ZO-1, DPP4 and fluorescein excretion (Fig. 10). Apart from ZO-1 expression, eDHs showed modest localised expression of DPP4. eDHs also exhibited localised fluorescein excretion at their apical sides. The results confirm the ability of eDHs to form tight junctions (indicated by ZO-1 expression), hepatic polarity (indicated by localised DPP4 expression) and functional bile canaliculi (indicated by localised fluorescein excretion).

\section{Discussion}

Similar to other epithelial cells, adult hepatocytes are polarised with an apical and basolateral surface, separated by tight junction proteins. In the liver, the apical poles of hepatocytes join to form channels (bile canaliculi), through which bile salts and other metabolites are expelled. Tight junction proteins support the formation of hepatic polarity by sealing neighbouring cells to prevent intermembrane diffusions, thus segregating bile canaliculi and cellular lumen. They also promote differential expression of membrane proteins on the apical and basal side of the hepatocytes. Due to this membrane compartmentalisation, export proteins that are actively involved in excreting bile salts/xenobiotic compounds are localised to the canalicular side of hepatocytes. The present study aimed to evaluate the hepatic functions and polarity of stem cell-derived hepatocytes (eDHs and $\mathrm{mDHs}$ ) and foetal heptocytes.

The hESC line RCM1 (13) was used for the study. RCM1 cells were differentiated using the same protocol that was developed for differentiating hESCs and pluripotent stem cells to hepatocytes efficiently $(3,4)$. During differentiation, RCM1 cells showed prominent changes in morphology, expressed hepatic genes (albumin, $\alpha$-fetoprotein, carbomyl phosphate synthetase, MRP2, CYP1A1 and HNF4 $\alpha$ ) and secreted hepatic proteins (albumin, $\alpha$-fetoprotein, $\alpha 2$-macroglobulin and fibronectin). They also exhibited mature hepatocyte characteristics, such as ICG uptake and glycogen deposition. These results confirmed the formation of functional hepatocytes from the RCM1 hESC line, as has been reported with other $\mathrm{hES}$ cell lines $(3,4)$. However, the study showed the presence of differentiation-resistant colonies within the eDH population, suggesting their unsuitability for transplantations, as the presence of contaminating ES cell colonies can result in teratoma formation following transplantation (14).

Differentiation of hMSCs from bone marrow (2), umbilical cord blood (2), adipose tissues (15), dental pulp (16) and foetal bone marrow (17) to hepatocyte-like cells has been reported previously. In the present study, human foetal pancreatic MSCs were isolated, cultured and analysed for the expression of essential MSC markers $(11,12)$. Cells were positive for CD90, CD105, CD49b, CD73, CD29 and CD44, and were negative for CD34, CD117, CD31 and CD45, confirming that the cultured cells were MSCs. The differentiation of hMSCs to a hepatic fate was carried out by following the 3 -stage protocol described previously (2), however, the cells were maintained in maturation medium for 35 days. This extended period in the maturation 
medium was designed to enhance their functional maturity (2). During differentiation the morphology of hMSCs changed and the cells expressed albumin, CK18 and hepatocyte-specific antigen, confirming hepatic differentiation. Flow cytometry analysis (albumin) and hepatic gene expression (albumin, $\alpha$-fetoprotein, carbomyl phosphate synthetase, HNF4 $\alpha$, CYP1A1 and MRP2) further confirmed the differentiation (16). The derived hepatocytes in the present study were negative for the expression of the biliary epithelial marker cytokeratin 19 (a biliary epithelial cytoskeleton protein) (18), confirming that the differentiation was specific to the hepatocyte lineage. $\mathrm{mDH}$ also exhibited facets of hepatic phenotype, such as ICG uptake and glycogen deposition (3). Such results confirmed the formation of functional hepatocytes from hMSCs isolated from the foetal pancreas. mDHs also expressed CD90, indicating a putative oval stem cell phenotype (10). However, they showed less secretion of hepatic proteins and a low level of $C Y P$ gene expression compared to other hepatocyte sources. They also showed heterogeneity in ICG uptake, indicating the functional heterogeneity of $\mathrm{mDH}$. This demonstrates their functional inefficiency for bioartificial liver (BAL) and in vitro toxicity studies, as these applications require highly functional hepatocytes.

In order to analyse the formation of functional hepatocyte polarity in stem cell-derived hepatocytes, the expression of the tight junction protein $\mathrm{ZO}-1$, the bile canalicular export protein MRP2, bile canalicular protein DPP4 and excretion of fluorescein was examined. eDHs showed functional tight junctions, however, bile canaliculi formation was not observed. Extracellular matrix is a requisite for polarising epithelial cells $(19,20)$ and collagen is widely used for polarising primary hepatocytes $(21,22)$. Collagen was used to make a layer of extracellular matrix over eDHs in the present study. eDHs cultured with collagen showed modest localised expression of DPP4 and fluorescein, confirming the formation of functional bile canaliculi in sandwich culture. These results show that the extracellular matrix has a profound influence even on the topology of stem cell-derived hepatocytes and emphasise the requirement to provide specific extracellular matrix components and factors required by adult hepatocytes/epithelial cells for their functional maturation. A recent study (23) reports similar advantages using a 3-dimensional (3D) system of culture.

Cell junctions are frequently involved in acute hepatotoxicity (24) and chronic hepatic diseases (25) and their loss is commonly evident during hepatocellular carcinoma (26). Therefore, junction proteins are used as an indicator for studying acute hepatotoxicity and chronic diseases, and for screening of non-genotoxic carcinogens (27). As eDHs form tight junctions, they can be considered useful as in vitro-based tight junction studies on acute and chronic hepatotoxicity and for screening genotoxic carcinogens. In addition, eDHs showed higher expression of CYP enzymes compared to the other alternate hepatocyte sources, confirming their suitability for in vitro toxicity studies and for BAL. As eDHs showed formation of polarity in sandwich culture, they may be able to perform better in the 3D environment of a BAL (28). As the 3-stage protocol of ESC hepatic differentiation mimics the embryonic developmental stages of the hepatocyte (3), differentiated hESC can also be used as a tool to study the development and formation of tight junctions and the process of hepatocyte polarisation.
Human foetal hepatocytes are also considered as a potent alternative human hepatocyte source $(29,30)$. A major source of human foetal hepatocyte is the liver of a therapeutically aborted foetus, and such abortions usually occur at the early stages of pregnancy. In the present study, human foetal hepatocytes isolated from the liver of terminated midtrimester foetuses showed albumin expression, glycogen storage and uptake of ICG confirming the efficient culture of functional human foetal hepatocytes (31). Additionally, human foetal hepatocytes showed hepatic polarisation with functional bile canaliculi formation. These results demonstrate the more mature aspects of human foetal hepatocytes compared to the pluripotent stem cell-derived hepatocytes. However, based on protein secretion and gene expression data, foetal hepatocytes were not as functionally mature as adult hepatocytes.

HNF $4 \alpha$ is an important hepatic transcription factor with active roles in hepatogenesis (32) and maintenance of hepatic functions $(33,34)$. Among the stem cell-derived hepatocytes examined in the present study, the expression of HNF4 $\alpha$ was much lower in less polarised $\mathrm{mDH}$ compared with the more polarised HepG2 cells and isolated human foetal hepatocytes. This demonstrates the profound role of HNF4 $\alpha$ in creating and maintaining cell polarisation even during the development of hepatocytes from stem cells and supports the previous reports in mature hepatocytes $(32,35,36)$. In addition, the more polarised cells, HepG2 and human foetal hepatocytes, showed less secretion of primitive hepatic proteins, such as $\alpha$-fetoprotein. These results correlate with previous studies on the effect of polarisation on hepatic functions, such as albumin secretion (37), bile secretion (38), glycogenolysis (39) and xenobiotic metabolism $(26,40,41)$ in adult hepatocytes. This correlation between functional efficiency and polarisation may be due to the better protein trafficking and compartmentalisation of cellular functions in polarised hepatocytes.

In conclusion, the present study has demonstrated that ESC-derived hepatocytes form functional tight junctions, have higher secretion of hepatic proteins and improved expression of CYP enzymes and hepatocyte transcription factor compared with mDHs. Collagen overlay to form a 2D-matrix sandwich improves the functional polarisation of ESC-derived hepatocytes and promotes the formation of bile canaliculi, emphasising the requirement for improved extracellular matrix environments, natural or synthetic, to further improve the function of pluripotent stem cell-derived hepatocytes for toxicology studies and BAL devices.

\section{Acknowledgements}

The authors would like to thank the Commonwealth Scholarship Commission for financial support (AAP) for the project. We thank all the members of the laboratories who have provided assistance throughout the project.

\section{References}

1. Palakkan AA, Hay DC, Anil Kumar PR, Kumary TV and Ross JA: Liver tissue engineering and cell sources: Issues and challenges. Liver Int 33: 666-676, 2013.

2. Lee KD, Kuo TK, Whang-Peng J, Chung YF, Lin CT, Chou SH, Chen JR, Chen YP and Lee OK: In vitro hepatic differentiation of human mesenchymal stem cells. Hepatology 40: 1275-1284, 2004. 
3. Hay DC, Zhao D, Fletcher J, Hewitt ZA, McLean D, Urruticoechea-Uriguen A, Black JR, Elcombe C, Ross JA, Wolf $\mathrm{R}$, et al: Efficient differentiation of hepatocytes from human embryonic stem cells exhibiting markers recapitulating liver development in vivo. Stem Cells 26: 894-902, 2008.

4. Sullivan GJ, Hay DC, Park IH, Fletcher J, Hannoun Z, Payne CM, Dalgetty D, Black JR, Ross JA, Samuel K, et al: Generation of functional human hepatic endoderm from human induced pluripotent stem cells. Hepatology 51: 329-335, 2010.

5. Gómez-Lechón MJ, Donato MT, Castell JV and Jover R: Human hepatocytes in primary culture: The choice to investigate drug metabolism in man. Curr Drug Metab 5: 443-462, 2004.

6. Tuschl G, Hrach J, Walter Y, Hewitt PG and Mueller SO: Serum-free collagen sandwich cultures of adult rat hepatocytes maintain liver-like properties long term: A valuable model for in vitro toxicity and drug-drug interaction studies. Chem Biol Interact 181: 124-137, 2009.

7. Schulze A, Mills K, Weiss TS and Urban S: Hepatocyte polarization is essential for the productive entry of the hepatitis B virus. Hepatology 55: 373-383, 2012.

8. Hannoun Z, Fletcher J, Greenhough S, Medine C, Samuel K, Sharma R, Pryde A, Black JR, Ross JA, Wilmut I, et al: The comparison between conditioned media and serum-free media in human embryonic stem cell culture and differentiation. Cell Reprogram 12: 133-140, 2010.

9. Hu Y, Liao L, Wang Q, Ma L, Ma G, Jiang X and Zhao RC: Isolation and identification of mesenchymal stem cells from human fetal pancreas. J Lab Clin Med 141: 342-349, 2003.

10. Masson NM, Currie IS, Terrace JD, Garden OJ, Parks RW and Ross JA: Hepatic progenitor cells in human fetal liver express the oval cell marker Thy-1. Am J Physiol Gastrointest Liver Physiol 291: G45-G54, 2006.

11. Pittenger MF, Mackay AM, Beck SC, Jaiswal RK, Douglas R, Mosca JD, Moorman MA, Simonetti DW, Craig S and Marshak DR: Multilineage potential of adult human mesenchymal stem cells. Science 284: 143-147, 1999.

12. Dominici M, Le Blanc K, Mueller I, Slaper-Cortenbach I, Marini F, Krause D, Deans R, Keating A, Prockop Dj and Horwitz E: Minimal criteria for defining multipotent mesenchymal stromal cells. The International Society for Cellular Therapy position statement. Cytotherapy 8: 315-317, 2006.

13. De Sousa PA, Gardner J, Sneddon S, Pells S, Tye BJ, Dand P, Collins DM, Stewart K, Shaw L, Przyborski S, et al: Clinically failed eggs as a source of normal human embryo stem cells. Stem Cell Res (Amst) 2: 188-197, 2009.

14. Tang C, Weissman IL and Drukker M: The safety of embryonic stem cell therapy relies on teratoma removal. Oncotarget $3: 7-8$, 2012.

15. Taléns-Visconti R, Bonora A, Jover R, Mirabet V, Carbonell F, Castell JV and Gómez-Lechón MJ: Hepatogenic differentiation of human mesenchymal stem cells from adipose tissue in comparison with bone marrow mesenchymal stem cells. World J Gastroenterol 12: 5834-5845, 2006.

16. Ishkitiev N, Yaegaki K, Imai $T$, Tanaka $T$, Nakahara $T$, Ishikawa H, Mitev V and Haapasalo M: High-purity hepatic lineage differentiated from dental pulp stem cells in serum-free medium. J Endod 38: 475-480, 2012

17. Wei X, Wang CY, Liu QP, Li J, Li D, Zhao FT, Lian JQ, Xie YM, Wang PZ, Bai XF, et al: In vitro hepatic differentiation of mesenchymal stem cells from human fetal bone marrow. J Int Med Res 36: 721-727, 2008.

18. Terrace JD, Currie IS, Hay DC, Masson NM, Anderson RA, Forbes SJ, Parks RW and Ross JA: Progenitor cell characterization and location in the developing human liver. Stem Cells Dev 16: 771-778, 2007.

19. Chambard M, Gabrion J and Mauchamp J: Influence of collagen gel on the orientation of epithelial cell polarity: Follicle formation from isolated thyroid cells and from preformed monolayers. J Cell Biol 91: 157-166, 1981.

20. Roskelley CD, Desprez PY and Bissell MJ: Extracellular matrix-dependent tissue-specific gene expression in mammary epithelial cells requires both physical and biochemical signal transduction. Proc Natl Acad Sci USA 91: 12378-12382, 1994.

21. Fu D, Wakabayashi Y, Ido Y, Lippincott-Schwartz J and Arias IM: Regulation of bile canalicular network formation and maintenance by AMP-activated protein kinase and LKB1. J Cell Sci 123: 3294-3302, 2010.

22. Palakkan AA, Anil Kumar PR and Kumary TV: An in vitro fluorometric assay for evaluating functional polarity of hepatocyte. Int J Bioassays 3: 1630-1636, 2014.
23. Gieseck RL III, Hannan NR, Bort R, Hanley NA, Drake RA, Cameron GW, Wynn TA and Vallier L: Maturation of induced pluripotent stem cell derived hepatocytes by 3D-culture. PLoS One 9: e86372, 2014

24. Kojima T, Sawada N, Zhong Y, Oyamada M and Mori M Sequential changes in intercellular junctions between hepatocytes during the course of acute liver injury and restoration after thioacetamide treatment. Virchows Arch 425: 407-412, 1994.

25. Sakisaka S, Kawaguchi T, Taniguchi E, Hanada S, Sasatomi K, Koga H, Harada M, Kimura R, Sata M, Sawada N, et al: Alterations in tight junctions differ between primary biliary cirrhosis and primary sclerosing cholangitis. Hepatology 33: $1460-1468,2001$.

26. Neveu MJ, Hully JR, Babcock KL, Hertzberg EL, Nicholson BJ, Paul DL and Pitot HC: Multiple mechanisms are responsible for altered expression of gap junction genes during oncogenesis in rat liver. J Cell Sci 107: 83-95, 1994.

27. Mally A and Chipman JK: Non-genotoxic carcinogens: Early effects on gap junctions, cell proliferation and apoptosis in the rat. Toxicology 180: 233-248, 2002.

28. Palakkan AA, Raj DK, Rojan J, Raj RGS, Anil Kumar PR, Muraleedharan CV and Kumary TV: Evaluation of polypropylene hollow-fiber prototype bioreactor for bioartificial liver. Tissue Eng Part A 19: 1056-1066, 2013.

29. Khan AA, Habeeb A, Parveen N, Naseem B, Babu RP, Capoor AK and Habibullah CM: Peritoneal transplantation of human fetal hepatocytes for the treatment of acute fatty liver of pregnancy: A case report. Trop Gastroenterol 25: 141-143, 2004.

30. Chen Y,Li J,Liu X,Zhao W, Wang Y and Wang X: Transplantation of immortalized human fetal hepatocytes prevents acute liver failure in $90 \%$ hepatectomized mice. Transplant Proc 42: $1907-1914,2010$

31. Weber A, Touboul T, Mainot S, Branger J and Mahieu-Caputo D: Human foetal hepatocytes: Isolation, characterization, and transplantation. Methods Mol Biol 640: 41-55, 2010.

32. Parviz F, Matullo C, Garrison WD, Savatski L, Adamson JW, Ning G, Kaestner KH, Rossi JM, Zaret KS and Duncan SA: Hepatocyte nuclear factor 4alpha controls the development of a hepatic epithelium and liver morphogenesis. Nat Genet 34 292-296, 2003

33. Hayhurst GP, Lee YH, Lambert G, Ward JM and Gonzalez FJ: Hepatocyte nuclear factor 4alpha (nuclear receptor 2A1) is essential for maintenance of hepatic gene expression and lipid homeostasis. Mol Cell Biol 21: 1393-1403, 2001.

34. Jover R, Bort R, Gómez-Lechón MJ and Castell JV: Cytochrome $\mathrm{P} 450$ regulation by hepatocyte nuclear factor 4 in human hepatocytes: A study using adenovirus-mediated antisense targeting. Hepatology 33: 668-675, 2001.

35. Battle MA, Konopka G, Parviz F, Gaggl AL, Yang C, Sladek FM and Duncan SA: Hepatocyte nuclear factor 4alpha orchestrates expression of cell adhesion proteins during the epithelial transformation of the developing liver. Proc Natl Acad Sci USA 103: 8419-8424, 2006

36. Cattin AL, Le Beyec J, Barreau F, Saint-Just S, Houllier A, Gonzalez FJ, Robine S, Pinçon-Raymond M, Cardot P, Lacasa M, et al: Hepatocyte nuclear factor 4alpha, a key factor for homeostasis, cell architecture, and barrier function of the adult intestinal epithelium. Mol Cell Biol 29: 6294-6308, 2009.

37. Hou DX, Arimura M, Fukuda M, Oka T and Fujii M: Expression of cell adhesion molecule and albumin genes in primary culture of rat hepatocytes. Cell Biol Int 25: 239-244, 2001

38. Nathanson MH, Rios-Velez L, Burgstahler AD and Mennone A: Communication via gap junctions modulates bile secretion in the isolated perfused rat liver. Gastroenterology 116: 1176-1183, 1999.

39. Stümpel F, Ott T, Willecke K and Jungermann K: Connexin 32 gap junctions enhance stimulation of glucose output by glucagon and noradrenaline in mouse liver. Hepatology 28: 1616-1620, 1998.

40. Shoda T, Mitsumori K, Onodera H, Toyoda K, Uneyama C, Imazawa $\mathrm{T}$ and Hirose $\mathrm{M}$ : The relationship between decrease in Cx32 and induction of P450 isozymes in the early phase of clofibrate hepatocarcinogenesis in the rat. Arch Toxicol 73 373-380, 1999 .

41. Hamilton GA, Jolley SL, Gilbert D, Coon DJ, Barros S and LeCluyse EL: Regulation of cell morphology and cytochrome P450 expression in human hepatocytes by extracellular matrix and cell-cell interactions. Cell Tissue Res 306: 85-99, 2001. 